\title{
可視光レーザー光源を用いたレーザーTVの開発
}

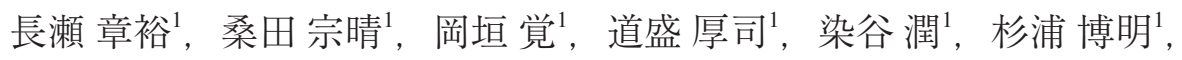

平野 嘉仁 ${ }^{2}$, 中村 聡 $^{3}$, 都出 英一 ${ }^{4}$, 吉原 徹 ${ }^{4}$, 寺松 滋則 ${ }^{4}$

${ }^{1}$ 三菱電機(株) 先端技術総合研究所 ( ₹ 617-8550 京都府長岡京市馬場図所1)

${ }^{2}$ 三菱電機(株) 情報技術総合研究所 ( ₹ 247-8501 神奈川県鎌倉市大船5-1-1)

3三菱電機(株) 生産技術センター（７661-8661 兵庫県尼崎市塚口本町8-1-1）

${ }^{4}$ 三菱電機(株) 京都製作所 ( $\bar{T} 617-8550$ 京都府長岡京市馬場図所1)

\section{Development of Laser TV that Uses Visible Laser Light Source}

\author{
Akihiro NAGASE, ${ }^{1}$ Muneharu KUWATA, ${ }^{1}$ Satoru OKAGAKI, ${ }^{1}$ Atsushi MICHIMORI, ${ }^{1}$ \\ Jun SOMEYA, ${ }^{1}$ Hiroaki SUGIURA, ${ }^{1}$ Yoshihito HIRANO, ${ }^{2}$ Akira NAKAMURA, ${ }^{3}$ \\ Eiichi TOIDE, ${ }^{4}$ Toru YOSHIHARA, ${ }^{4}$ and Shigenori TERAMATSU ${ }^{4}$ \\ ${ }^{1}$ Mitsubishi Electric Corporation, Advanced Technology R\&D Center, 1 Zusho, Baba, Nagaokakyo, Kyoto 617-8550 \\ ${ }^{2}$ Mitsubishi Electric Corporation, Infomation Technology R\&D Center, 5-1-1 Ofuna, Kamakura, Kanagawa 247-8501 \\ ${ }^{3}$ Mitsubishi Electric Corporation, Manufacturing Engineering Center, 8-1-1 Tsukaguchi-Honmachi, Amagasaki, Hyogo 661-8661 \\ ${ }^{4}$ Mitsubishi Electric Corporation, Kyoto Works, 1 Zusho, Baba, Nagaokakyo, Kyoto 617-8550
}

(Received January 6, 2011)

\begin{abstract}
We have successfully developed a new category of television, a laser TV, which uses a visible-ray laser. Our new laser TV has a color gamut that is approximately twice that of conventional liquid crystal TVs owing to the monochromaticity of the laser, which is one of the specific features of the laser system. The high efficiency of laser energy conversion, together with the optical systems optimized to our developed laser, managed to reduce the power consumption of the new laser TV to a level less than a half that of a liquid crystal television of the same size. On the other hand, the high coherency of the laser causes scintillation, and this degrades the quality of pictures. To solve this problem, we have succeeded in developing a new moving screen, which greatly contributes to the production of a laser TV system with high image quality.
\end{abstract}

Key Words: Laser TV, Display, Visible laser, Wide color gamut, Low consumption

\section{1. はじめに}

ディスプレイの性能を評価する指標の一つに色域があ る. CRTがデイスプレイデバイスの主流であった時代, ディスプレイの色域は, CRTに用いられていた蛍光体の 発色性と，それを基準に定められた色空間 $\mathrm{SRGB}^{1)}$ に よって制限され，例えばMansell Color Cascade769色の約 $55 \%$ 程度しか表現できていなかった。 2000年頃から普 及し始めたプラズマディスプレや液晶ディスプレイと いった，いわゆフラットパネルディスプレイは，映像信 号のデジタル化, 高解像度化とも相まって, 画像の精細 感を飛躍的に向上させたが, 色域に関しては, 従来の範 囲を大きく上回るものではなかった。

2006年にIEC (International Electrotechnical Commission) で発行された動画を対象とした拡張色空間規格 xvYCC ${ }^{2)}$ は, Mansell Color Cascadeの769色の100\%を包 含し, sRGBでは表現できなかった彩度の高い色までを
忠実に再現することを可能にする．マルチメディア符号 化の規格であるMPEG(Moving Picture Experts Group)や, HDMI (High-Definition Multimedia Interface) といった伝送 系でも相次いでxvYCCを準拠し始めたことで，広色域 画像を表示する環境が整いつつあり，デイスプレイの広 色域化に対する期待も高まっている。デイスプレイの色 域を広げる方法には, 各原色の色純度を高める方法と, 多原色化が考えられる。我々はこれまでに，6原色LED バックライト液晶モニタ ${ }^{3)}$ や6原色プロジェクション $\mathrm{TV}^{4)}$ といった多原色ディスプレイを多種開発してきた。そし て今回，更なるディスプレイの広色域化を目指し，光源 に単色性の高い3原色の可視光レーザーを採用すること で，通常の液晶ディスプレイに比べて2倍の色域を持つ レーザーTVを新たに開発した。エネルギー変換効率に 優れるレーザーを光源に用い，またカラーフィルターや 液晶で光源からの光を遮断しないレーザーTVは，大画 面でも消費電力は少なく, 昨今の省電力化のニーズにも 
適合した新カテゴリーのデイスプレイである.

\section{2. レーザーTVの概要}

レーザーTVの開発は, 2005年から本格的に開始し， 52型，56型のレーザーTVを試作し検証を行ってき た ${ }^{5,6)}$. その後2008年に北米市場向けに65型の超薄型 レーザーTVを開発7) し製品化した。更に2010年には75型 のレーザーTVも開発し, 現在北米と日本で販売してい る. Fig. 1は65型レーザーTVの外観写真である。レー ザーTVはいわゆる背面投射型のディスプレイである。

レーザーの高指向性を利用することで, 光学系を小口径 にすることが出来るため, 光学系の小型化が可能にな る。また，新たに開発した，投射レンズと非球面ミラー で構成される超広角の投写光学系を搭載したことで, レーザーTVの奥行きは, 65型で約 $270 \mathrm{~mm}$ と, 従来の背 面投射型ディスプレイと比較して大幅に薄くすることが 可能になった。 さらに, 液晶やプラズマのようにパネル 面周辺に電極を設ける必要が無いため, 狭額縁スタイル が可能になった。

Fig. 2は65型レーザーTVの概略光学系を示す図であ る. 赤, 緑, 青の各レーザー光源から発せられた光はラ イトパイプに導かれる。 ライトパイプではマイクロディ スプレイ(レーザーTVではデジタルマイクロミラーデバ イス ${ }^{8)}$ を使用)に均一に光が当たるように光を成形す る。そして，マイクロデイスプレイで空間的に変調され た光は投射光学系を介してスクリーンに広角投影され る.

レーザーTVの最大の特徴は，色域が広いことであ る.

Fig. 3はレーザーTVの色域を示す図である. 原色点が スペクトル軌跡上にあるレーザーTVでは, CIE 1976 USC色度図 ( $u^{\prime} v^{\prime}$ 色度図)において, $\mathrm{NTSC}^{9)}$ 比175\%の広 色域を達成する。これは, 従来の液晶ディスプレイの約 2倍の色域である。

レーザーTVのもう一つの特徵は省エネルギーであ る. 半導体レーザーのエネルギー変換効率は, LEDや CCFLのエネルギー変換効率と比較して優れていること

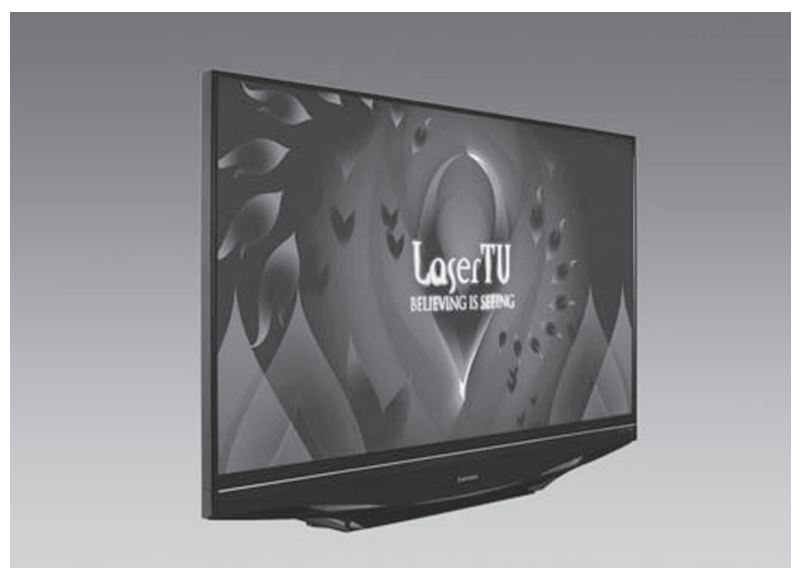

Fig. 1 65type laser TV.

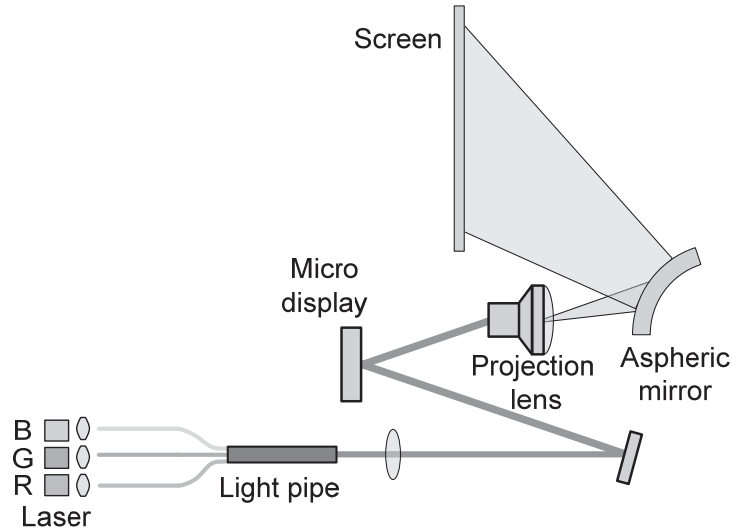

Fig. 2 Structure of 65type laser TV.

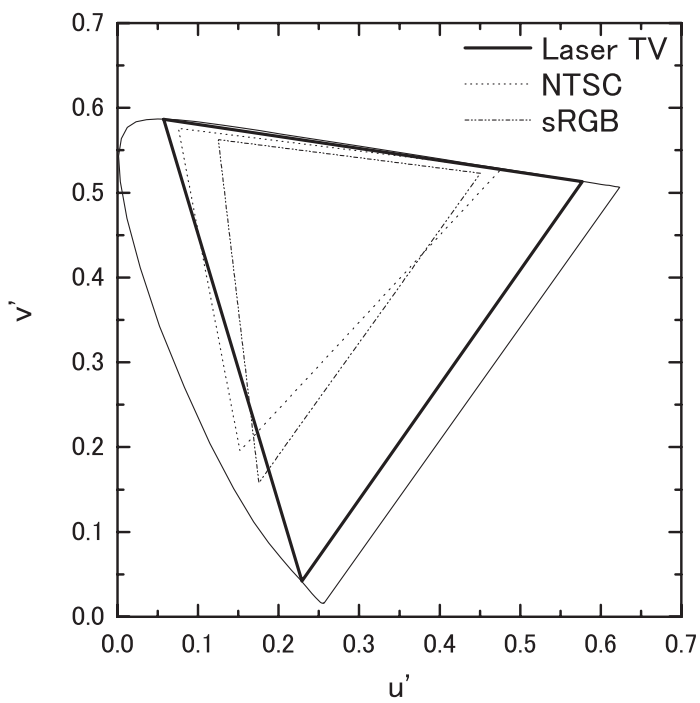

Fig. 3 Color Gamut of laser TV.

に加え，液晶ディスプレイのようにカラーフィルターや 透過型液晶等で光のロスが発生することもないため, 例 えば65型のレーザーTVは $500 \mathrm{~cd} / \mathrm{m}^{2}$ の高輝度でありなが ら, 定格 $135 \mathrm{~W}$ と同サイズのプラズマディスプレイや液 晶ディスプレイの半分以下の低消費電力になっている.

\section{3. レーザーTVの要素技術}

3.1 レーザー光源ユニット

Fig. 4は，65型レーザーTV用に開発したレーザー光源 ユニットである。薄型のレーザーTVを実現するため, RGBのレーザーモジュールの他，レーザーモジュール の泠却機構，レーザー駆動電源およびレーザー制御回路 が厚さ106 mmのユニット内部に納められている.

各レーザーモジュール内部には，半導体レーザーと カップリング光学部品が組み込まれ, 半導体レーザーか ら出射された光は, カップリング光学系を介して，レー ザー光源ユニット外部にある，マイクロデバイスや投射 光学系などで構成される光学エンジンに送られる。また レーザーモジュールからの発熱は, ヒートパイプ, ファ ン，ペルティ工素子を組み合わせることで構成されてい 
る冷却機構によって効率よく排熱されている.

\section{2 レーザー光源}

今回，採用したRGBの3原色のレーザーの波長は，青 が447 nm, 緑が532 nm, 赤が640 nmの3色である。青, 赤は半導体レーザーを使用しているが, 緑は半導体レー ザーから直接高出力の発振を得るのが困難なため, 赤外 発振させた基本波を波長変換して生成している.

Fig. 5は新たに開発した緑のレーザー ${ }^{10)}$ の内部写真で ある. $808 \mathrm{~nm}$ の励起レーザーアレイ, $\mathrm{Nd}: \mathrm{YVO}_{4}$ 導波路, PPMgLN (Periodic-poled MgO-doped lithium niobate) 導波 路で構成されており， $\mathrm{Nd}: \mathrm{YVO}_{4}$ 導波路から出力される $1064 \mathrm{~nm}$ の基本波をPPMgLNに通すことで532 nmに変換 している.

Table. 1に各レーザーモジュールの特性を示す。65型 で500 cd/ $/ \mathrm{m}^{2}$ の輝度を得るため, 各レーザーモジュール のピーク出力は赤が $6.3 \mathrm{~W}$, 緑が $5.0 \mathrm{~W}$, 青が $8.1 \mathrm{~W} ゙$ 合 計19.4 Wの出力を得ている。この比率は, 画面に表示さ

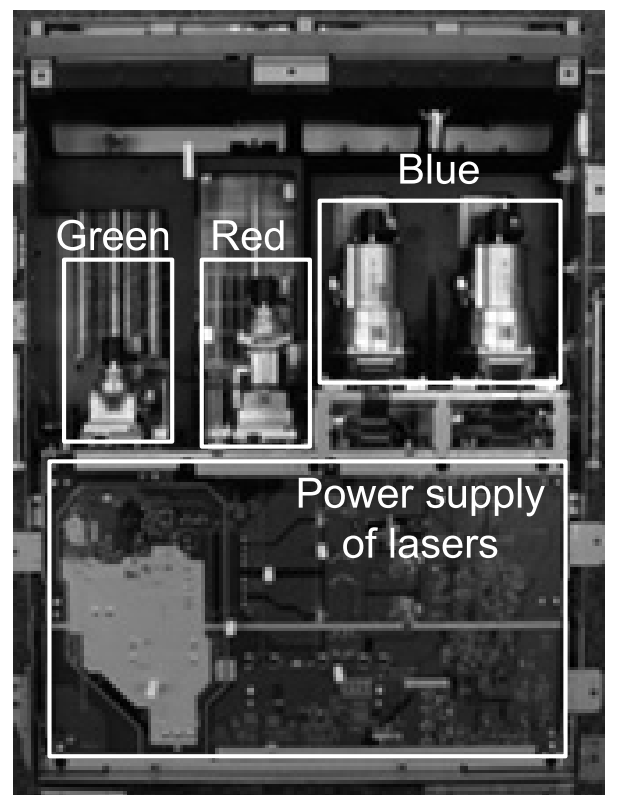

Fig. 4 Laser source unit for 65type laser TV.

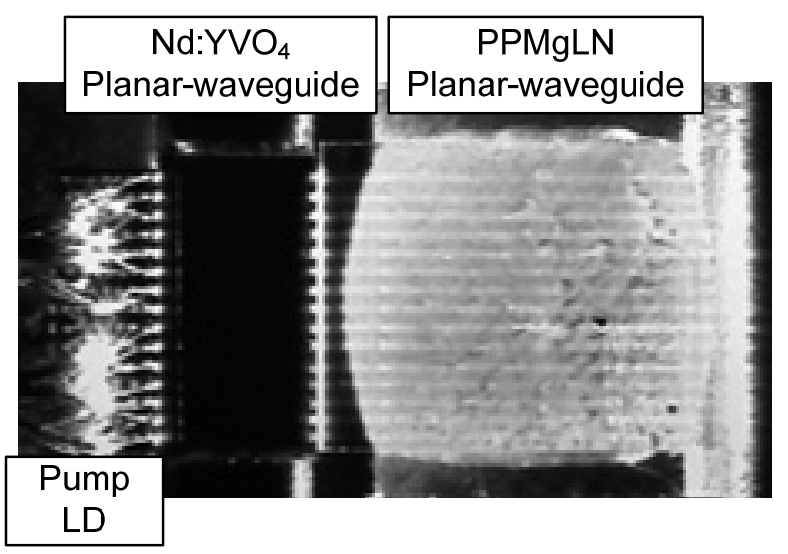

Fig. 5 Detail structure of new green laser.
れる白の色温度(ホワイトバランス)が最適になるように 設計されている。

また, Table. 1に示すように各レーザーモジュールは マルチエミッタで構成されている。ママルエミッタで構 成されるレーザーモジュールは，たとえ任意の1エミッ 夕に故障が発生しても致命的な光量の低下につながらな いことに加え、複数の位相の異なる光をスクリーンに投 射するため，スペックルパターンの角度多重化によるス ペックルコントラストを低減させる効果も期待され $ろ^{11)}$.

\section{3 光源駆動制御}

Fig. 6は640 nm付近の分光視感曲線であり, $640 \mathrm{~nm}$ の 感度で正規化したものである。人の目は555 nm付近の 黄緑色で最も視感度が高く，640 nm付近は波長が長く なるに従い，急激に視感度が劣化する。

レーザーはジャンクション温度が変化すると, エネル ギー変換効率が変化するとともに，出射波長も変化す る. 特に赤のレーザーの出射波長は約 $0.2 \mathrm{~nm} / \mathrm{K}$ の温度依 存性があり，例えば，レーザーのパッケージ温度が $10{ }^{\circ} \mathrm{C}$ 変化すると, 出力が $10 \%$ 程変化する

Fig. 7は, レーザーTVの光源制御システムの構成を示 した図である。RGBの各レーザーモジュールには，温 度コントローラと，フォトセンサーも組み込まれてい る。温度コントローラーはレーザーの温度が温度指令值 になるように制御すると共に，温度測定結果を制御マイ コンに出力する。フォトセンサーはレーザーの発光状態 を検知し，結果を制御マイコンに出力する。また，各 レーザーモジュールの近くにはスイッチング方式の定電

Table 1 Specific of laser module.

\begin{tabular}{cccc}
\hline & Red & Green & Blue \\
\hline \hline Wavelength & $640 \mathrm{~nm}$ & $532 \mathrm{~nm}$ & $447 \mathrm{~nm}$ \\
\hline Peak power & $6.3 \mathrm{~W}$ & $5.0 \mathrm{~W}$ & $8.1 \mathrm{~W}$ \\
\hline Number of emitter & 20 & 15 & 14 \\
\hline Modules volume & $60 \mathrm{ml}$ & $30 \mathrm{ml}$ & $220 \mathrm{ml}$ \\
\hline
\end{tabular}

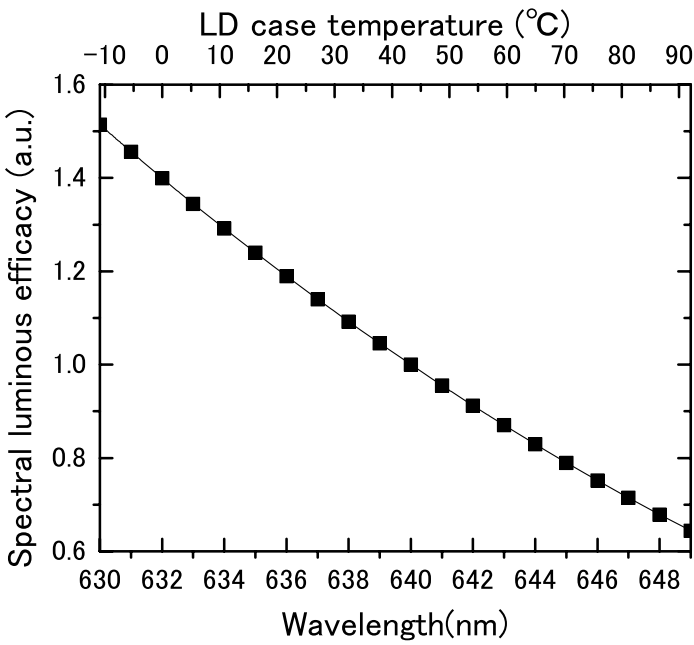

Fig. 6 Spectral luminous efficacy around $640 \mathrm{~nm}$. 


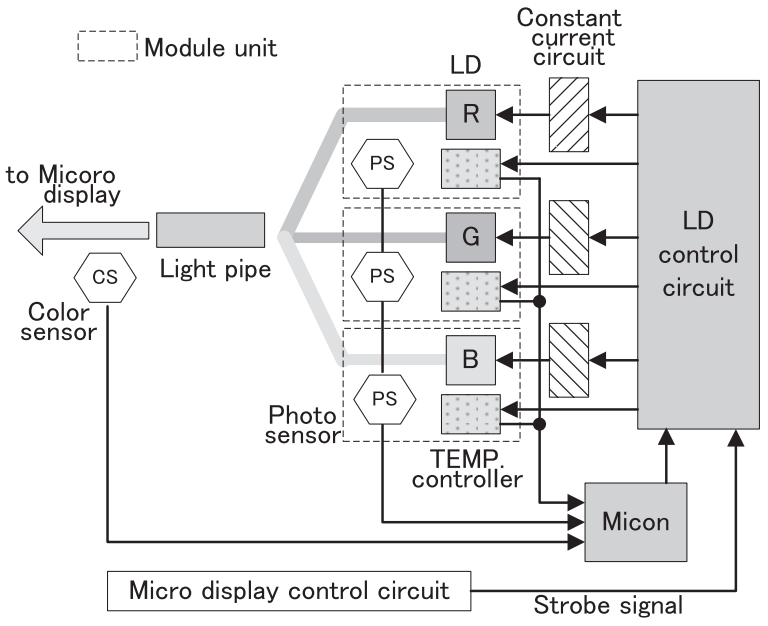

Fig. 7 Laser control system of laser TV.

流回路が配置されている。定電流回路は，レーザー制御 回路から出力される電流指令值と, マイクロディスプレ イ制御回路から送られてくるレーザーの点灯タイミング を示すストローブ信号に応じて，レーザーに電流を供給 する.

ライトパイプの出口にはカラーセンサーが設置してあ る. カラーセンサーは各レーザー光源から出力される光 量を検出し, 結果を制御マイコンに出力する。制御マイ コンではカラーセンサーの検出結果を解析し, 各レー ザーからの出力が予め決めておいた比率になるように各 レーザーの電流指令值を更新すると共に，その結果を レーザー制御回路に出力する。レーザー制御回路では, ストローブ信号に同期させ，制御マイコンから出力され てくる各種指令值を, レーザーモジュールに出力する.

レーザーTVでは各レーザーの温度管理以外に，各 レーザーから出力される光量の検出結果に基づき, レー ザーに供給する電流量調節するフィードバック制御を導 入することで，ホワイトバランスの劣化を防いでいる。

\section{4 フィールドシーケンシャルカラー表示}

単板のマイクロデイスプレイで光源からの光を空間変 調するレーザーTVは，いわゆる継時加法混色型のディ スプレイである. 入力する1フレーム分の映像信号を赤, 緑, 青の映像を表示させるサブフィールドに分解し, そ れらサブフィールドを順次表示させるため, フィールド シーケンシャルカラー表示とも呼ばれる本方式は, 表示 フィールド以外の色の光源は消灯させることが出来るた め, 消費電力の低減に効果的である反面, 観測者の視線 の移動に伴い色割れが視認されてしまうことが知られて いる ${ }^{12)}$.

色割れは, RGB各色の1周期表示期間である色表示周 波数や, 網膜上の像の移動速さ, 画面輝度, 観測者の視 力などに依存していることが分かっており，衝動性眼球 運動(サッケード)などの速い眼球運動が生じた場合など は, 色表示周波数が $1 \mathrm{kHz}$ 超えていても視認されてし まうという報告もある ${ }^{13)}$.

一般的な液晶の応答速度がmsオーダーなのに対し，
マイクロミラーデバイスの応答速度は $10 \mu \mathrm{s}$ オーダーと 非常に高速である。しかし，UHPランプから放出される 白色光をRGBの回転式カラーフィルターを用いて継時 的に濾波して3原色の光を得る従来のプロジェクション 方式のディスプレイでは，カラーフィルターの回転に用 いるモーターの性能により色表示周波数を高めるのには 限界があった。モーターの回転数をR $\mathrm{rpm}, \mathrm{RGB} の$ 繰り 返し数を $n$ とすると, 色表示周波数 $f_{\text {color }}$ は,

$$
f_{\text {color }}=\frac{n \cdot R}{60}
$$

但し，色表示周波数 $f_{\text {color }}$ は入力する映像信号周波数の整 数倍数. 安価に入手可能モーターの回転数は $10000 \mathrm{rpm}$ 程度までであるため, 仮にモーターの回転数が $10800 \mathrm{rpm}, \mathrm{RGB}$ 繰り返し数 $n$ が2であったとしても, 色表示周波数 $f_{\text {color }}$ は360 Hzしか得られない.

Fig. 8はレーザー光源の立ち上がり特性の一例を示し た図であり，マイクロディスプレイ制御回路からスト ローブ信号が出力された後の出力光量(スクリーンから の出射光)の時間変化をプロットしたものである.レー ザー制御回路では, 各色の発光タイミングの微調整を 行っているため，ストローブ信号を受信した後，定電流 回路に電流が流れ出すまでに若干の遅延が発生する。さ らに，レーザー発振後も出力が安定するまでに若干の時 間がかかるが，これらは枌オーダーの話であり，回転式 カラーフィルターを用いていた従来の方式と比べると桁 違いに速いスイッチング動作が可能である。このレー ザー光源システムの高速スイッチング特性を利用し, レーザーTVでは色表示周波数 $f_{\text {color }}$ を $1680 \mathrm{~Hz}$ で動作させ ており，色割れが視認される可能性を大幅に軽減してい る。

\section{5 シンチレーション対策}

レーザー光源をデイスプレイに用いる場合に問題にな るのが，レーザー光のコヒーレントの高さに起因するス ペックルノイズである．特にスクリーンをレーザー光が 通過する際に生じる過干渉ノイズは画質に対する影響が

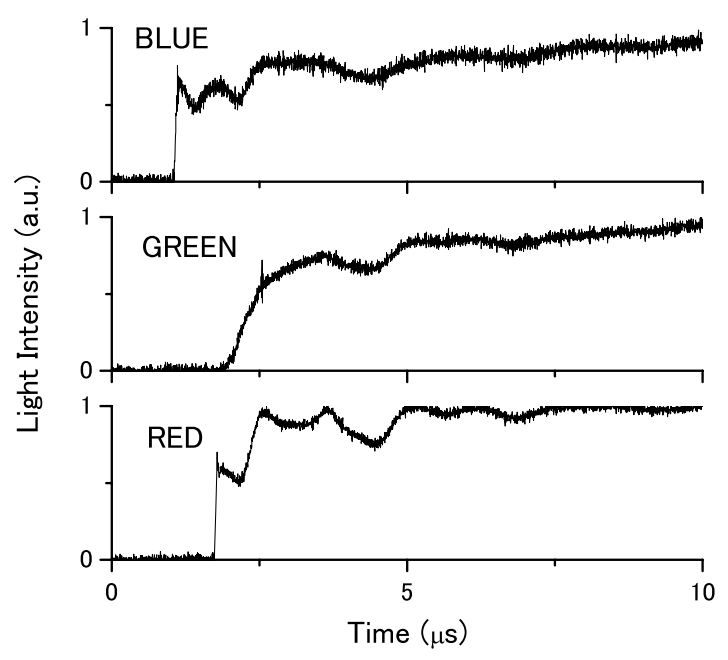

Fig. 8 Risetime of light source system. 
大きく，我々はこれをシンチレーションと呼んでいる. シンチレーションを除去する有効な方法として, 先に述 ベたマルチエミッタ光源を用いた角度多重以外にも，例 えばスクリーンを動かす方法が古くから知られてい $ろ^{14)}$.

65型のレーザーTV用のスクリーンの重量は，求めら れる剛性の高さから $10 \mathrm{~kg}$ 近くにもなる。この重いスク リーンを，ディスプレイに求められる長時間の耐久性を 確保しつつ摇動させ，またレーザーTVの特徴である狭 額縁スタイルに摇動機構を収めるためには，シンプルな 駆動機構を導入する必要がある. 今回我々は, 複数の支 持バネによりスクリーンを筐体に接続するとともに，位 相の異なる2つのリニアモーターを使い， スクリーンを 回転させる機構を開発した。

Fig. 9は，摇動スクリーンの構造を示す図である。 ス クリーンは，フレネルスクリーン，レンチスクリーンの 2枚で構成されており，内側のフレネルスクリーンを摇 動させる。フレネルスクリーンはその周囲を金属製フ レームで固定され, フレームは複数のL字型のバネで筐 体と繋げてある。 スクリーンは筐体下部には2つのリニ アモーターが設置されており, 各々のモーターの動作方 向はスクリーンの重心方向へ向いている. 時刻 $t$ におけ るリニアモーターの軸方向の変位, $M A(t), M B(t)$ は, リ ニアモーターの振動振幅を $C$, 周期を $T$, 駆動位相差を $\gamma$ とした場合,

$$
\left\{\begin{array}{l}
M A(t)=C \sin \left(\frac{2 \pi t}{T}\right) \\
M B(t)=C \sin \left(\frac{2 \pi t}{T}-\gamma\right)
\end{array}\right.
$$

ここで，2つの振動軸間の角度である配置角度を $\alpha$ とす ると,

$$
\gamma=\pi-\alpha
$$

時刻 $t$ を消去し, $x y$ 平面上における軌道軌跡を表すと,

$$
x^{2}+y^{2}=C^{2} \sin ^{2} \gamma
$$

となる。これは, 任意の配置角度 $\alpha$ に応じた位相差 $\gamma$ を 与えて2つのリニアモーターを駆動させると，スクリー

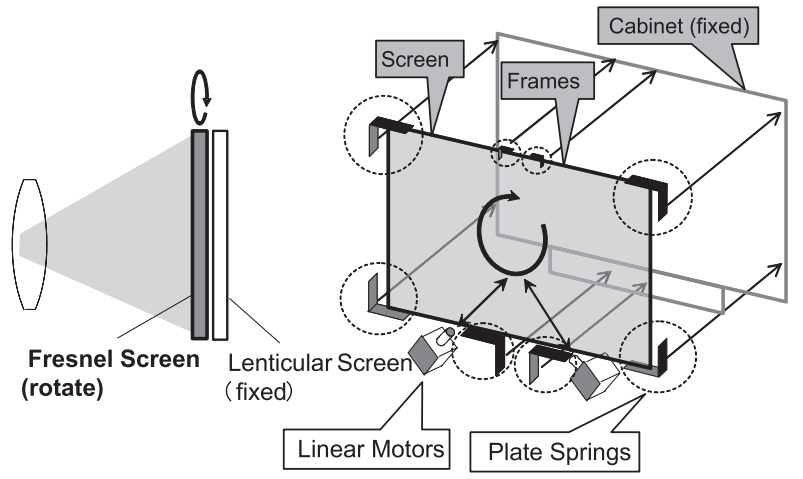

Fig. 9 Moving screen system for laser TV.
ンが駆動半径 $C \sin \gamma$ の運動することを示している.

レーザーTVでは，リニアモーターの配置角度 $\alpha$ を約

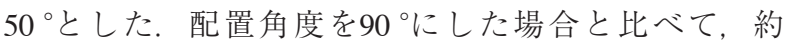
$25 \%$ の駆動損失を発生させるが，外観のデザインを優 先した結果である。また駆動仕様は，セットの加振力限 界，スクリーンの固有周波数，そしてシンチレーション の評価結果を考慮して最適化を行った結果, 半径約 $0.3 \mathrm{~mm}$, 周波数約 $3 \mathrm{~Hz}$ で駆動している.

\section{4. まとめ}

我々は，3原色の可視光レーザーを用いた新しいカテ ゴリーのディスプレイであるレーザーTVを開発化し た。レーザー光源と共に，それに最適化した，駆動電 源，信号処理技術，光学エンジン，スクリーン，筐体構 造を新たに開発したことにより，レーザーTVは従来の 液晶ディスプレイの約2倍の広色域表示が可能になった ことに加え，高画質かつ低消費電力を実現している.

\section{参考文献}

1) IEC 61966-2-1 Amendment 1: Multimedia systems and equipment - Colour measurement and management-Part 2-1: Colour management - Default RGB colour space - sRGB (2003).

2) IEC 61966-2-4 First edition: Multimedia systems and equipment - Colour measurement and management - Part 2-4: Colour management - Extended-gamut YCC colour space for video applications - xvYCC (2006).

3) 香川周一, 金子 英之, 染谷潤, 杉浦 博明 : 三菱電機技法 80 (2006) 508.

4）長瀬章裕, 香川周一, 染谷潤, 桑田宗晴, 笹川智広, 杉浦 博明, 宮田彰久：映像情報メディア学会技術報告 31 (2007) 21.

5) J. Someya, Y. Inoue, H. Yoshii, M. Kuwata, S. Kagawa, T. Sasagawa, A. Michimori, H. Kaneko, and H. Sugiura: Society for Information Display 2006 International Symposium Digest of Technical Papers, San Francisco, June, 2006, p.1134.

6) H. Sugiura, M. Kuwata, Y. Inoue, T. Sasagawa, A. Nagase, S. Kagawa, N. Watanabe, and J. Someya: Society for Information Display 2007 International Symposium Digest of Technical Papers, Long Beach, May, 2007, p.12.

7) H. Sugiura, T. Sasagawa, A. Michimori, E. Toide, T. Yanagisawa, S. Yamamoto, Y. Hirano, M. Usui, S. Teramatsu, and J. Someya: Society for Information Display 2008 International Symposium Digest of Technical Papers, Los Angeles, May, 2008, p.854.

8) 新地修：映像情報メデイア学会誌 51 (1997) 479.

9) SMPTE 170M: Composite Analog Video Signal-NTSC for Studio Applications.

10) Y. Hirano, T. Yanagisawa, S. Yamamoto, Y. Koyata, M. Okano, T. Hamaguchi, A. Nakamura, T. Yagi, and H. Sugiura: Society for Information Display 2008.

11) 黒田和男, 山本和久, 栗村直編：解説レーザーディスプ レイ（オプトロニクス社，東京，平成22年）p.186.

12) 森峰生, 畑田豊彦, 石川和夫, 最勝寺俊大, 和田修, 中村旬一, 寺島 信義：映像情報メディア学会誌 53 (1999) 1129 .

13）岡本成継, 杉野道幸, 向殿 充浩：映像情報メディア学会 技術報告 25 (2001) 73 .

14) S. Lowenthal and D. Joyeux: J. Op. Soc. Am. 61 (1971) 847. 